\title{
Jyväskylän Ikääntyvien yliopisto
}

\section{Ikääntyvien yliopistotoiminnan taustaa}

Yhdistyneet kansakunnat järjesti kesällä 1982 konferenssin "World Assembly on Ageing",johon myös Suomi osallistui. Kokouksessa hyväksyttiin kansainvälinen asiakirja "The Vienna International Plan of Action on Ageing", jossa esitettiin suosituksia vanhuspolitiikan kehittämiseksi. Esille nousi kysymys ikääntyvien ihmisten koulutuksellisesta tasaarvosta. Koulutuspolitiikkaa suositeltiin laajennettavaksi siten, että elinikäisen oppimisen idea toteutuisi myös ikääntyvän väestönosan kohdalla.

Kolmannen iän yliopistot Euroopassa ja Ikääntyvien sekä Ikäihmisten yliopistot Suomessa ovat olleet yksi tapa toteuttaa ja kehittää varttuneiden ihmisten opiskelumahdollisuuksia. Ikääntyvien yliopisto aloitti toimintansa Jyväskylässä terveystieteen laitoksen ja Jyväskylän kesäyliopiston aloitteesta vuoden 1985 tammikuussa. Helsingin yliopiston Lahden tutkimus- ja koulutuskeskus aloitti puolestaan syksyllä 1985 Ikäihmisten yliopisto -nimisen avoimen korkeakouluopetuksen.

Kyseessä on kansainvälisestikin suhteellisen uusi ilmiö. Vastaavanlaista toimintaa järjestettiin ensimmäisen kerran Ranskassa Toulousissa sijaitsevassa yliopistossa vuonna 1973 Kolmannen iän yliopisto -nimikkeellä. Toiminnan alullepanija professori Pierre Vellas määritteli Kolmannen iän yliopiston tehtäväksi erilaisten seminaarien ja luentotilaisuuksien sekä tutkimustoiminnan kehittämisen.

Toiminnan syntyyn vaikuttaneita yhteiskunnallisia ja sosiaalisia taustatekijöitä voidaan etsiä rakenteellisista muutoksista. Ikääntyvän väestönosan määrä lisääntyy jatkuvasti. Ennusteiden mukaan Euroopan väestöstä on arvioitu olevan vuonna 2025 noin 24,7 \% 60 vuotta täyttäneitä (vuonna 1975/17,4 \%). Nykyisellään yli 65-vuotiaiden osuus on Suomen väestöstä keskimäärin 12,5\%. Myös ikääntyvien ihmisten jäljellä oleva elinaika on pidentynyt merkittävästi viime vuosikymmeninä. Nykyisin se on 65-vuotiailla naisilla keskimäärin 17 vuotta ja miehillä vastaavasti 13 vuotta.
Vanhemmat ikäluokat ovat entistä paremmin koulutettuja ja monissa maissa on vanhusten terveydentila kohonnut.

Puhuttaessa kolmannen iän yliopistoista Englannissa tai Ranskassa on todettu, että toiminta ei mahdu valmiiden koulutuspoliittisten suunitelmien sisään. On myös vaikea ennustaa minkälaisiksi kyseiset yliopistot kehittyvät tulevaisuudessa. Idean yksi yhteinen nimittäjä on toiminnan spontaani, epävirallinen luonne ja kyky ottaa vastaan ajan haasteita. Toinen yhteinen tekijä on opiskelijoiden innostunut mukanaolo ja keskinäinen yhteistyö. Toiminnan piirteisiin kuuluu myös omaehtoisuus. Yliopistoissa opiskelevat ikääntyvät ihmiset ovat kehitelleet pitkälti itse erilaisia opintokokonaisuuksia ja luoneet kokonaisvaltaisia ja omia tarpeitaan vastaavia ohjelmia. Samalla on vaikutettu itse koulutuksen ja oppimisen -käsitteisiin ja yleiseen mielipiteeseen ikääntyvän ihmisen oppimismahdollisuuksista.

\section{Toiminnan lähtökohdat}

Jyväskylän Ikääntyvien yliopiston lähtökohtia voidaan tarkastella sekä suhteessa vanhuspolitiikalle asetettuihin tulevaisuuden suuntiin että elinikäisen opiskelun idean ja aikuiskasvatuksen kehittämiseen. Yksi lähiajan suurista haasteista liittyy yhteiskunnan rakenteelliseen muutoks̀een, väestön vanhenemiseen. Yli 65yuotiaiden määrällinen kasvu asettaa uusia vaatimuksia vanhuspolitiikan kehittämiselle kulttuuritoimen ja sosiaali- ja terveydenhuollon osalta.

Toiminnan alkuvaiheessa on kuitenkin merkityksellistä, että korostetaan erityisesti ikääntyvien ihmisten opiskelumahdollisuutta. Vastaavanlaista älyllistä ja ihmisen persoonallisuuden kehittymistä mahdollistavaa toimintaa ei ole ollut tarjolla myöhäiseen aikuisikään ehtineille. Toisaalta nykyinen opiskelumuoto antaa uskoa vanhenevan ihmisen kehittymismahdollisuuksiin, lisää opiskelijoiden omanarvontuntoa ja itseluottamusta sekä edistää näin myös myönteistä vanhuskäsitystä. 
Ikääntyvien yliopisto on osa aikuiskasvatusta; toiminnan lähtökohtia voidaan tarkastella myös suhteessa elinikäisen opiskelun ja avoimen korkeakoulun periaatteisiin. Jatkuvan opiskelun periaatteen mukaan tulee jokaisella ihmisellä olla kaikkina ikäkausinaan mahdollisuus oman persoonallisuutensa kehittämiseen järjestelmällisen ja joustavan opiskelun avulla. Tärkeitä päämääriä ovat persoonallisuuden monitahoisen kasvun turvaaminen ja koulutuksellisen tasa-arvon edistäminen. Avoimen korkeakoulun tavoitemäärittelyissä korostuu niinikään koulutuksellinen tasa-arvo. Toiminta perustuu korkeakoulujen ja eri aikuisoppilaitosten väliseen yhteistyöhön tarjoten tavoitteellisen korkeakoulutasoisen opintomahdollisuuden valmiutensa eri tavoin hankkineille aikuisille.

Ikääntyvien yliopisto -idea edellyttää toiminnallisten lähtökohtien avartamista yli sen, mitä virallisesti ajatellaan koulutuksella ja kasvatuksella. Vanhuksilla on runsaasti elämänkokemusta ja tietoa. Tässä mielessä olisi harhaanjohtavaa puhua koulutuksesta. Kyse on pikemminkin jo olemassaolevan kokemuksen syventämisestä ja uusien näkökulmien etsimisestä.

Oppiminen voitaisiin määritellä Rooman klubin raportin tavoin inhimillistä aloitteellisuutta korostavaksi lähestymistavaksi sekä tietoon että elämään. Siihen sisältyy modernissa maailmassa välttämättömien uusien tieteellisten menetelmien, uusien taitojen, uusien asenteiden ja uusien arvojen hankinta ja harjoitus. Oppiminen on uusiin tilanteisiin valmistava prosessi.

Raportissa käytetään myös käsitettä uudistava oppiminen, joka tarkoittaa uusien tilanteiden ennakointia ja oman yhteisön kehittämiseen osallistumista. Yksinomaan asiantuntijavaltainen järjestelmä ei anna riittävästi edellytyksiä ymmärtävälle oppimiselle, sillä suunnitelmat ja toimintastrategiat valmistuvat usein ilman konkreettista kosketusta sosiaaliseen todellisuuteen. Oppimiselle tärkeät yhteisölliset arvot saattavat jäädä huomioimatta ja oppimistapahtumasta tulee passiivista ja säilyttävää.

Osallistuminen on sekä eri ihmisten välistä vuorovaikutusta, kykyä kuunnella ja ymmärtää että tulla oppimisen kautta tietoiseksi ongelmien uusista ratkaisutavoista. Omakohtaisesti tiedostamalla ja löytämällä mielekkäitä asiayhteyksiä yksilöt ja ryhmät voivat saada lisää toimintavalmiuksia oman elämänsä, ympäristönsä ja yhteiskuntansa kehittämisessä. Oppimisella on näin ollen hermeneuttinen ja emansipatorinen luonne. Ikääntyvien yliopisto -idean toteutumisen ehtona on kaikkien osapuolten keskinäinen yhteistyö. Idea edellyttää opiskelijoiden itsemääräämisoikeutta ja osal- listumista toımınnan kehittämiseen, mutta myös oikeutta olla halutessaan anonyymi.

Toiminta on luonteeltaan uutta ja kokeilevaa. Mitään valmiita toteuttamismalleja ei ole käytettävissä eikä myöskään liene mielekästä kehittää opintosuunnitelmia ja -tavoitteita irrallaan käytännön toiminnasta. Ulkomaisten kokeilujenmukaan kolmannen iän yliopistoissa opiskelevat ihmiset ovat suunnanneet itse opiskelumuotoja. Yliopistoihin on muodostunut ns. opiskelevia yhteisöjä, joissa vuorottelevat sekä keskinäinen yhteistyö että itseopiskelu. Tämän ohella ovat kadonneet myös tiukat rajat opiskelijoiden ja opettajien väliltä, sillä kukin voi olla vuorollaan sekä neuvovana että vastaanottavana osapuolena.

Toiminnan luonteeseen kuuluu myös tutkimuksen kehittäminen. Tutkimusta voivat harjoittaa toisaalta opiskelijat itse tai sitä voidaan tehdä yhteistyössä yliopistojen tutkijoiden ja opiskelijoiden kanssa. Tutkimuksen asema on merkittävä sekä vakiinnutettaessa hyviksi koettuja oppimismetodeja ja toimintatapoja että tuotettaessa tietoa ikääntymisen ja oppimisen välisestä problematiikasta.

\section{Ikääntyvien yliopiston tavoitteet}

Vanhuspolitiikan tavoitteena on hyvän elämänlaadun ja hyvinvoinnin turvaaminen, vanhusten itsenäisyyden kunnioittaminen ja heidän sosiaalisen ja henkisen vireytensä säilyttäminen. Ikääntyvän väestön sivistyksellinen, sosiaalinen ja taloudellinen panos nähdään tärkeäksi koko yhteiskuntapolitiikalle. Yhteiskuntapolitiikan ja erityisesti vanhuspolitiikan toivotaan pyrkivän ratkaisuihin, jotka tukevat ikääntyneiden tảsa-arvoa, oikeuksia, täysipainoista elämää, osallistumista ja vaikuttamista sekä turvallisuutta muun väestön joukossa.

Ikääntyvien yliopiston tavoiteasetteluissa on yhtenevyyttä vanhuspolitiikan tavoitteiden kanssa. Tavoitteita voisi yleisellä tasolla pyrkimykseksi muuttaa puutteelliseen tietoon perustuvia käsityksiä vanhenemisesta ja vanhuudesta. Tärkeitä näkökulmia ovat myös ikääntyvien ihmisten elämänlaadun parantaminen tuottamalla valmiuksia osallistumiseen ja omien oikeuksien tiedostamiseen sekä eri ikäryhmien välisen vuorovaikutuksen edistäminen.

Koska Ikääntyvien yliopisto on uusi ja uriaan etsivä toimintamuoto, ovat tavoitteet kuitenkin vain viitteellisiä. Ne muotoutuvat ja kehittyvät toiminnan myötä. 
Tavoitteena on

muuttaa puutteelliseen tietoon

perustuvia käsityksiä vanhenemisesta

tuottaa ikääntyville ihmisille

valmiuksia osallistumiseen ja

tiedostamiseen

luoda ikääntyville ihmisille

edellytyksiä säilyttää oman elämänsä

hallinta mahdollisimman pitkään

lisätä vuorovaikutusta sekä eri

ikäryhmien välillä että ikääntyvien välillä

\section{Tähänastinen toiminta}

Jyväskylän Ikääntyvien yliopisto aloitti toimintansa vuoden 1985 tammikuussa. Tällä hetkellä mukana on 220 aktiivista opiskelijaa. Suurin ikäryhmä on 57-66 vuotiaat, joita on kaikista opiskelijoista noin puolet. Vanhin opiskelija on 86-vuotias ja nuorin 39-vuotias. Ilmoittautuneista on valtaosa naisia eli noin 3/4. Kansakoulun on käynyt noin $35 \%$, keskikoulun noin $26 \%$ ja korkeakoulututkinnon on suorittanut noin $12 \%$

Toimintamuotoina ovat olleet sekä lukukausittain järjestettävät studia generalia -tyyppiset luentosarjat että seminaarityöskentely.

Luentosarjojen aiheet ovat koostuneet vanhenemiseen ja vanhuuteen liittyvästä problematiikasta (mm. vanhenemisen biologiset, psyykkiset ja sosiaaliset muutokset, terveydenhoidolliset kysymykset, vanhukset taiteessa ja taiteilijoina, eri kulttuureiden vanhuuskäsitykset jne.). Tämän lisäksi on tarkasteltu myös ajankohtaisia kysymyksiä (mm. tietoyhteiskunta, työelämän muutokset, modernin kaupunkimiljöön vaikutus ihmissuhteisiin jne.).

Seminaariryhmien aihepiireinä ovat liikunta ja terveys, ihmissuhteet, kirjallisuus ja ATK. Ryhmissä on sovittu yhteisesti käsiteltävistä teemoista. Ryhmän vetäjän ja ulkopuolisten alustajien ohella myös ryhmäläiset ovat suunnitelleet ja pitäneet alustuksia. Keväällä 1986 työskennellyt ATK-ryhmä tuotti "Jyväskylän ikä-älyköt" -nimisen kurssikoosteen.

Seminaarityöskentelyä laajennetaan jatkossa perustamalla uusia ryhmiä. Suunnitteilla on $\mathrm{mm}$. perinneryhmä, joka jakautuisi erilaisiin sektioihin osanottajien taitojen ja intressien mukaan (esim. muistelmia kirjoittavat, keskustelevat ja tutkimusmetodeja opiskelevat ryhmät). Ryhmien työskentelytapaa on myös tarkoitus selkeyttää siten, että eriytetään sekä harraste- että tavoiteryhmiä. Harrasteryhmissä ikääntyvien ihmisten sosiaalis-

yhteiskunnallisen aseman parantaminen

oman elinympäristön toimintaan

osallistuminen — omien oikeuksien

tiedostaminen

fyysisen, psyykkisen ja sosiaalisen

elämänlaadun parantaminen

mielekkäiden sosiaalisten roolien löytäminen

toimitaan entiseen tapaan luennoiden ja keskustellen; tavoiteryhmät työskentelevät pitkäjänteisemmin antaen osanottajille erilaisia käytännöllisiä ja teoreettisia valmiuksia (esim. liikuntaryḥmän ohjaus, tutkimustoiminta, vapaaehtoistyö).

Ikääntyvien yliopiston yhteyteen on suunniteltu perustettavaksi ns. emeritusakatemia. Emeritusakatemia on eläkkeelle jäävien yliopiston opettajien foorumi, jonne he voivat kokoontua keskustelemaan ajankohtaisista kysymyksistä, järjestää seminaari- ja julkaisutoimintaa tai toimia yhteistyössä gerontologian tutkijoiden ja opiskelijoiden kanssa.

Ikääntyvien yliopisto hyväksyttiin kesällä 1986 kansainvälisen liiton "The International Association of the Universities of the Third Age" jäseneksi. Kansainvälistä yhteistoimintaa jatketaan järjestämällä kongresseja ja tutustumalla ulkomaisiin kokeiluihin.

Ikääntyvien yliopiston toiminta palvelee osaltaan Jyväskylän yliopistossa käynnistyvää vanhusten kuntoutus- ja aktivaatiotutkimusta.

\section{Lähteet}

Botkin W.J. (et al.), Oppimisen uudet haasteet, Raportti Rooman klubille, Espoo, 1981.

Brussel P., Senior Citizens Challenge Traditional Education: The French Experience. Educational Gerontology, vol. 10 no. 3, 1984.

Convergence, International Journal of Adult Education. vol. XVIII, no. 1-2, 1985.

Midwinter E., Mutual Aid Universities. London, 1984.

Sysiharju A-L., Varttuneet opiskelijoina. Kasvatus 2/ 1986.

Vanhuspoliittinen katsaus. Vanhusten elinoloja ja vanhuspolitiikan ajankohtaisia haasteita kartoittava raportti. Sosiaali- ja terveysministeriö. Suunnittelusihteeristö. Helsinki 1986.

Vanhusten palveluiden kehittäminen. Vanhushuoltotoimikunnan mietintö. Komiteanmietintö 1984/60. Helsinki 1984. 